2016

\title{
Indian Peasant Women's Activism in a Hot Cold War
}

Elisabeth Armstrong

Smith College, earmstro@smith.edu

Follow this and additional works at: https://scholarworks.smith.edu/swg_facpubs

Part of the Women's Studies Commons

\section{Recommended Citation}

Armstrong, Elisabeth, "Indian Peasant Women's Activism in a Hot Cold War" (2016). Study of Women and Gender: Faculty Publications, Smith College, Northampton, MA.

https://scholarworks.smith.edu/swg_facpubs/2 


\section{Indian Peasant Women's Activism in a Hot Cold War}

The twentieth century pan-Asian women's movement did not begin as a peasant women's movement, but by the 1940s

it became one. Women who gained their livelihood through agricultural labour brought energy, relevance and an exhilarating unpredictability to the pan-Asian women's movement as a whole. They powerfully shaped the post-war women's movement in the Global South, and pressured both communist and anticommunist international women's movements in the Global North. As a mass movement, peasant women formed the core of the leftist women's movement in the Global South. Yet the histories of the Cold War give little space for peasant women's activism in the mid-20th Century. The bifurcation between the Euro-American West and the Soviet East in standard narratives of the Cold War obscures the formative class struggles that shaped anti-imperialist women's activism in the Global South.

Mass movements of women in the Global South reveal two critical tacets that Cold War scholars of the 1940s and 1950s too often ignore. First, local, national and regional class conflict rather than international arm-twisting fueled the communism/ anti-communism polarity in Asia. In the context of India, that is, class-based political differences between peasant women and elite women split the formerly unified nationalist women's movement, not Soviet or Western promises of support. Second. the Cold War in Europe was a hot war across the continents of Asia and Africa. Peasant women's organising as a mass force emerged during the intensified military repression against 
insurgent populations by colonial forces.' Anti-imperialism integrally shaped these leftist women's movements in the Global South as a critical site for pan-Asian and Afro-Asian women's solidarity. They wielded this solidarity among colonial and postcolonial nations in the international women's forums reenergized at the end of the war in Europe and Japan.

Scholars have documented varied pan-Asian movements against imperialism that began in the 1920 s, led by Sun Yat-sen in Japan, and the Kuomindang in China, alongside communist parties in China and the USSR. ${ }^{2}$ In India, the nationalist movement recognized the importance of mobilising the largest numbers of Indian people into its struggle for an independent nation-state. The largest numbers of Indian people were peasants - conceived widely to include artisans, small farmers, landless agricultural workers, tenant farmers and fisher people. By the 1920s, they were central to the widespread nationalist anti-colonial mobilizations across the country. ${ }^{3}$ As with peasant men. Indian peasant women's activism developed out of nationalist, communist, socialist, indigenous and anti-caste peasant movements in the 1930 s and 1940 s. $^{4}$ Peasant groups,

1 For regional examples, sce Anthony Short. The Communis Imurrestion in Jhlaya, 1948-1961, New York: Cranc, Russalk \& Company, 1975; Caroline Elkins, Imperial Ambitions; Tbe Untolo Stury of Britnin's Gulag in Kenyn. New York: Henry Holt and Co., 2005.

2 Carolien Stolte, "'Enough of the Great Napoleans!" Raja Mahendra Pralap's Pan-Asian projects (1929-1939)' Ainkern Aitin Studies 46 (2) (2012), pp. 403-23: Anna Belagurova, "The Chinese International of" Nationalities: The Chinese Communist Party, the Comintern, and the foundation of the Malayan National Communist Party, 1923-1939", Sourrinal of Glolot History 9 (2014). Pp. 447-70.

"Cyanendra Pandey, The Arcendency of Conymene in Uhw Pradarb: Clinw, Commanity sms Nation in Not bern Imtha, 1920-1941), London: Anthem Press, 1978; Ranajit Guha, Elementary supectu of Perumt Insurgency in Cuhmial Indiu, New Delhi: Oxford University Press, 1983; David Hardiman. Peautme Nafisulatist of Gujarat, 19/7-1954, New Delhi: Oxlord University Press, 1981.

+ In India, peasant women joined internationalist communist parties through antj-casteist movements in the South and in Maharashtra, 
called kisan sabbas, sought to build rural men's leadership and to represent the demands of dispossessed agricultural people. In India until 1945, peasant women were peripheral to rural organising campaigns, holding no leadership positions in the All India Kisan Sabha, the India-wide and multi-party farmers" organization that began in 1936. By 1945, separate meetings for peasant women were structured into their national conferences. ${ }^{5}$ Peasant women's activism also developed from the nationalist women's movement, particularly in the late 1930s and 1940s.

The All India Women's Conference (AIWC) began in 1927 as a nonsectarian, social reform organization to promote Indian women's education and health. ${ }^{6}$ The AIWC was not directly linked to the nationalist movement originally, nor did it espouse the cause of women's activism. Its members were from elite, princely families and the educated middle classes, though these women espoused a wide range of political viewpoints and affiliations. At its inception, at least, the AIWC seemed an unlikely instigator of peasant, poor and working class women. Yet, as its name attests, AIWC aspired to represent and lead all women of India under its umbrella, regardless of their religion, language or political party affiliation. By the early 1940s, not only did AIWC overtly support women's activism in the Indian independence movement, but it also sought to reach the masses of rural, peasant Indian women.

Sarojini Naidu was a leading figure in India's nationalist feminism of the mid-twentieth century. She joined the Indian freedom movement in 1905, spoke to Viceroy of India Lord

peasant movements in Andhra, Bengal and Punjab, as well as lefist campaigns linked to the anti-colonial women's movement.

"See 'Among Kisan Women', People's IPru, 11 I (46), May 13, 1945, p. 2. This article detailed peasant women's participation in the $\Lambda$ IKS conlerence in Netrakona. Bengal, April 7-9, 1945. Their leadership in the All India Kisan Sabha and even in the Bengal Provincial Kisan Sabha, however, was still negligible.

'- Aparna Basu and Bharati Ray, Women', Sirnggle: A Hurtory of lbe All Imlin Wimen', Conference, 1927-2012. New Delhi: Manohar, 2003. 
Chelmsford and Secretary of State for India Edwin Montagu in favor of women's right to vote in 1917, and was the Congress Party president in 1925. She led the AIWC as president in 1930. For nationalist members like Naidu, to describe AIWC as a 'non-political' group meant an omni-political one. All women, they argued, were welcome. In 1944, Naidu defended the right of communists and members from the Muslim League to participate in the Indian National Congress. 'In times of great crisis', she said, 'humanity is greater than all political parties. ${ }^{7}$ Addressing Congress Party members she added, 'Why did you not organize - ban or no ban - to give relief to the distressed? Why did you leave the work of relief to the communists?'8 Naidu pointed to the power communists derived by their active relief work in the countryside and cities during the Bengal famine that began in 1943. Others had not been as involved. It meant that - in Bengal at least - their mass roots had not taken hold. Nationalist feminists like leltist feminists sought to strengthen the women's movement by organising amongst rural peasant women. Their methods of mobilizing rural, dispossessed women to support the Indian independence movement, however, were not attuned to peasant women's demands or their methods of organising. Without addressing peasant women's daily needs for survival alongside the systemic injustice that made their survival so precarious, nationalist feminist efforts fell short.

Leftist regional women's groups, like the Mabila Alma Rakılba Samiti (MARS) in Bengal, and the Punjab Women's Self-Defence League also organized among working class and poor women in cities and peasant women in rural areas. Leftist organizers allied (and often shared membership) with the AIWC in these struggles over wages, fair working conditions, and food distribution. During the Bengal famine in 1943 and 1944, the AIWC with other women's groups set up and ran rehabilitation centers for

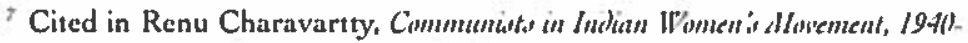
1950, New Delhi: People's Publishing House, 1980, p. 70.

"Ibid. 
destitute women in the cities of Kolkata, Krishnanagar and Barisal. ${ }^{9}$ This mass-based work increased AIWC's membership numbers dramatically. By April 1944, AIWC's membership had risen two and a half times over one year, from 10,000 to 25,000 women. ${ }^{10}$ The AIWC convention resolutions from 1942 to 1946 reveal the political pressures of holding together social reform feminism with nationalist feminism and leftist feminism. AIWC conference resolutions show AIWC's increasing breadth of issues: in favor of food distribution 'for the entire population' in 1943 during the Bengal famine, against the 'barbaric practice of whipping of political and other prisoners' also in 1943, against the Nizam of Hyderabad's sexual and physical violence against Andhra women in 1945, and in favor of postal workers' rights in 1946." Its increasing radicalism clashed with the entrenched interests of its powerful members and began to tear at the seams of AIWC's proclaimed 'All India' unity.

In 1946, the AIWC finally split over its restrictive membership policies that charged dues too costly for most women to pay. The desire to lead peasant women did not mean the desire to organize as equals alongside them or to heed their demands. Nationalist feminists allied with social reformist members to maintain the AIWC's higher membership dues, thus excluding the large numbers of working class and peasant women radicalized by their rural activism. In December 1946, the AIWC membership allowed local clubs to decide whether to reduce their fees to four annas (a quarter of one rupee) from three rupees to allow more rural and working class women to join. Without the explicit support for the fee reduction at the national level, communist members lost the possibility of

"Annual Report of the Member-in-charge of Social Section', Hansa Mehta papers, Subject file \#7. Nehru Memorial Muscum and Library (herealier NMML), New Delhi, India.

16 '18th Conference in Hyderabad', Rubni, 1, 1, February 1946, p. 21.

"'Resolutions Passed by the Standing Committee of the All-India Women's Conf'erence, at their meeting in Bombay on the 29th and 30th May 1943', Renuka Ray papers, folder \#7, NMML. 
transforming AIWC into a national women's organization that represented all Indian women. After this defeat, most of its left-wing members withdrew from AIWC to concentrate their efforts organising a national, mass-based women's movement from the scattered regional leftist women's groups. ${ }^{12}$

Importantly, communist and socialist women did not leave the AIWC because of its anti-communism as such. Many nationalist leaders of AIWC sought a unified group of women from all political parties, and wanted to lead peasant women. Instead, leftist members left the one welcoming national women's organization to create a women's movement substantively shaped and led by peasant women. After 1946, leftist women's groups gave voice to increasingly radical demands at local and regional levels, since they had no alternative national women's organization. They sought to overturn gendered caste hierarchies, rural power relations between the landed and the land-poor, and women's sexual norms as a unified class politics, not niche demands for indigenous, Dalit and working class women and men. ${ }^{13}$ The anti-violence demands of the peasant women in India contronted local patriarchal and casteist norms as well as the in tertwined character of European colonialism with regional feudal class relations. ${ }^{14}$ Leftist women's groups also joined the fight by peasant groups for greater rights to land and crops, for example, in the Tebhaga movement of Bengal in 1946-1947. They worked alongside activists in the Communist Party of India (CPI) and in communist and socialist unions, and student groups. They developed a mass-based leftist women's movement in India because of the large numbers of women organized into women's groups, but also in the politics they espoused.

12 Renu Chakravarty, p. 200.

13 Adrienne Cooper, Sharecropping and Sbarecroppen' Struggled in Bengal, 19501950, Kolkata: K.P. Bagchi and Co., 1988.

14 Peter Custers. W'omen in the Tebbaya Upriwing: Rural Pour IFomen and Rerolutionary Leateribip (1946-47). Kolkata: Naya Prokash, 1987. pp. 22 25. 
After 1945, Euro-American aligned organizations like the International Alliance of Women actively wished to recruit Asian women's groups into their fold on anti-communist terms, and they sought to reach (and guide) these masses. In no small part, peasant women's militancy on class issues, alongside their antiimperialism, spurred Euro-American, anti-communist interest in peeling away some nationalist and Third Worldist women from the communist movement. On the pan-Asian level, peasant women's politics also shaped the Cold War discourse of the international women's movement. The Women's International Democratic Federation gained respect among lefrist and nationalist women's groups in Asia for adding a forceful denunciation of colonialism to its anti-fascist programme. ${ }^{15}$ Asian and North African participants in the opening meeting of WIDF in December 1945 successfully fought to widen their politics from one of 'anti-tascism' to one of 'anti-imperialism'.

\section{THE THREE STRANDS OF INDIAN FEMINISM}

Before independence in 1947, the Indian women's movement had three distinct, yet often overlapping feminist ideologies: social reformist, nationalist, and leftist.

Social reform feminism sought to allow women access to education and other material benefits and fostered political subjectivities for women's activism in the private sphere. Social reformist feminism by the 1930 s was inter-communal. It linked women and men from different religions and regions to push for wider resources for women and girls. Social reform activists sought changes to restrictive norms for girls and women largely from within the private spheres of the familial and the religious or ethnic community.

Nationalist feminism saw improvement of women's education and health as goals that could support women's

th Elisabeth Armstrong, 'Belore Bandung: The Anti-Imperialist Women's Movement in Asia and the Women's International Democratic Federation', Signu, 41, 2, Winter 2016. 
equal rights and their full participation in public life. Mrinalini Sinha argues that nationalist feminism supported an openly political and public subject bounded not by familial community but by the patriarchal benevolence of the nation. ${ }^{16}$ Through a focus on legal reform, nationalist feminists in the AIWC and elsewhere sought to make laws to support women's rights to equal citizenship. Women's full citizenship also contested the legitimacy of the British colonial order in India, since neither Indian women nor Indian men enjoyed this status.

Leftist feminism shared with nationalist feminism a commitment to anti-colonialism, and women's legal and state-based inclusion into the public sphere. However, leftist feminism was also anti-imperialist and anti-capitalist. Lefitist feminists organized towards a vision of women's emancipation that transformed class politics and the public sphere itself. They envisioned a public that welcomed the full participation of all people of India in its economic, cultural and political life.

These three stands of the Indian women's movement - social reformism, nationalism and leftism - jostled for space within the All India Women's Conference in the 1930s and 1940s. While they shared some overlapping concerns, activists within AIWC did not fully agree on how to pursue their founding goals of women's education and rights. Nationalist feminists within AIWC relied on a strong nation-state and the stability of dominant social norms to transition to independent governance. Leftist feminists sought to harness the possibilities for new emancipatory social orders out of the mass mobilizations for independence. They sought to dismantle old forms of social hierarchy in gender and caste and economic hierarchies of class to produce more transformative changes for a decolonized nation-state. The sexual politics of women's activism in the 1940s, in no small part because of these political aspirations, exposed critical differences between leftist

16 Mrinalini Sinha, Spectern of Jfolber ImTiar The Glotal Restructuring of an Empire, Durham and London: Duke University Press, 2007. 
and nationalist feminists within AIWC. Even the most sincere appeals to a secular and cross-political unity could not paper over these differences.

\section{SOCIAL REFORM FEMINISM}

Indian social reform feminism began in the mid-19 $9^{\text {th }}$ Century when Christian British colonial officials and men from the educated Muslim and Hindu Indian elite challenged gendered, hierarchal religious practices and social relations. Social reform movements focused predominantly on improving the conditions of Indian women's lives as wives, widows and daughters. While often characterized simply as a means to justify colonial rule through the British 'civilizing mission', social reformism could not contain all Indian women's issues. Historians like Padma Anagol caution us to remember that even early in the social reform movement. Indian women enthusiastically supported social reform campaigns. ${ }^{17}$ Due to the active participation of Indian women, by the twentieth century, social reform feminism had gained significant traction as both an international and national movement. Moreover, it began to undermine rather than shore up the legitimacy of English rule over India.

Opposition to AIWC's social reformist politics was fierce. The heightened sexual politics of women's education and health access dogged its work. During the second year of the All India Women's Conference, in 1928, the Begum of Bhopal agreed to take the post as president and attended the organization's meetings. The Begum had been hugely influential in her support for women's education during the late nineteenth and early twentieth century, but the lessons she had learned about educated women's respectability sounded outmoded by the

17 Padma Anagol's study of Indian women's writing in Marathi journals show that '(n)ineteenth-century Indian leminists embraced and utilized the rhetoric of the "civilizing mission" with alacrity". See "Feminist Inheritances and Foremothers: The Beginnings of Feminism in Modern India", IFmen', Hirtrry Review 19 (4), September 2010, p. 533. 
1920s. ${ }^{18}$ Kamaladevi Chattopadhyay, a prominent nationalist activist, was the general secretary who ran the AIWC alongside the Begum during its first four years. She recounted members' mischievous response to the Begum's horror of dance in an unpublished memoir. Chattopadhyay wrote, 'We had been on the significant role of dancing in education. When this was mentioned the President interrupted sharply, raising her arm in protest. ' I can't have dance in any form discussed or approved in this session while I preside". ${ }^{19}$ At the beginning of the twentieth century, social reformists including the Begum of Bhopal, had to fight stereotypes of educated women as women without honour or morals. Dancing, as the profession of courtesans and sex workers, became the brush to tarnish early women's schools like the Women's College of Aligarh Muslim University. ${ }^{20}$ Thus, for the Begum, dancing in women's schools was a stereotype to be thoroughly shunned. For the active members of AIWC in the 1920s however, fear of dancing was an antiquated joke. In Chattopadhyay's account,

The Begum's objections did not impede the position of AIWC: Zimha Lazarus, Principal of Women's College in Bangalore was on her leet advocating this forbidden form. She was charming and humorous with a very agile and resourcelul brain. With hardly a pause, she nodded acceptance ol' the Chair's ruling, but went on with her speech advocating movements, rhythm, music, speaking with speed and blurring occasionally over d-a-n-c-e, which only

in In the lounding of Aligarh's premier women's college, then called the Muslim Girls' School and Hostel, the fight to create a girl's boarding school faced rumours that it laught music and dance to produce nautch girls for men's entertainment. See Rakhshanda Jalil, a Rebel and Her Caute:

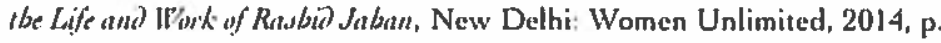
17.

19 Kamala Chattopadhyay, 'Some reminiscences of the 1929 European tour of the IAW in Berlin', n.d., Speches and Writings, Kamala Chattopadhyay papers, NMML.

2. Jalil, A Reliel ass) Her Catuse, p. 17. 
a discerning ear could catch. So the resolution was passed, with small changes to make it less blatant and hurt the old lady's confirmed susceptibilities. ${ }^{\text {.1 }}$

In Chattopadhyay's recounting, the political edge of AIWC's agenda for women's social reform took precedence over the older gender order represented by the Begum. Definitions within AIWC of acceptable politics for a women's organization faced new challenges in the 1930 s with the intensity of the anticolonial movements-some non-violent, others violent-all of which had prominent women activists. AIWC's campaigns began to widen the boundaries of a gender-mixed public sphere from women's education to women's active involvement in governance and oppositional politics.

\section{NATIONALIST FEMINISM}

Nationalist feminists within AIWC sought to make anticolonial activism an acceptable politics for women. ${ }^{22}$ First, they lifted the ban on members' participation in politics in the early thirties. ${ }^{23}$ Second, they encouraged women from all political parties to join and participate in their activities. Sinha discusses the Child Marriage Restraint Act, or Sarda Act passed in 1929, as the turning point for the development of nationalist feminism as distinct from social reform feminism. ${ }^{24}$ In many ways, the Sarda Act was a classic social reform law that raised women's age of consent for marriage. The Sarda Act was not embedded in any of the religious personal laws, and was the first civil piece of legislation that addressed women's rights. Its

"Kamala Chattopadhyay, 'Some reminiscences of the 1929 European tour' of the IAW in Berlin', NMML.

22. Suruchi Thapar-Bjorkert, IFanen in the Natimal Movement: Unseen Faces, Unbear Vuice, 1950-42, New Delhi: Sage Publications, 2006.

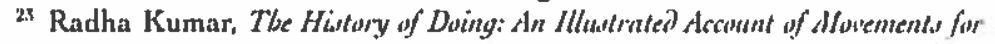
Women's Rigbts and Feninism in India, 18010-1991), New York: Verso, 1993, pp. $68-69$.

${ }^{24}$ Sinha, Specters of dotber India. 
civil and thus universal character marks a radical break from other social reform campaigns. For opponents, it undermined the power of religious personal laws that governed women by their religious affiliation. As a civil law, it curbed the power of religious authorities over legislation regarding marriage, women's property rights, among other issues considered familial in nature.

Sinha argues that the terrain for women's activism shifted social reform feminism itself because women were not only the objects to be protected by law, but also its activist subjects fighting to protect themselves. She writes, "The unprecedented involvement of women and of women's organizations in the debates surrounding the Sarda Act underwrote a crucial political development: the construction of women as both subjects and the objects of social reform in India'. ${ }^{25}$ The universalized category of 'citizen' that included Indian women and Indian men allowed the emergence of a distinctly nationalist feminism during the $20^{\text {th }}$ century. But there were limits to the nationalist feminist subject set by the nation-state. Gandhi invoked an idea of the nation that placed all women into one political community; this was a unity that took the place of, rather than eradicated, other community strictures. Thus, the dominant Gandhian vision for nationalist leminism imagined a community where the nationstate provided women the defining location for their active citizenship. However, this protective and patriarchal role of the postcolonial nation-state 'trumped the recognition of women's autonomy' as citizens or activists. ${ }^{26}$

\section{LEFTIST FEMINISM}

Through the AIWC, nationalists like Sarojini Naidu were allied to women in revolutionary terrorist movements, such as Kalpana Datta Joshi, who participated in the Chittagong Armory

25. Ibid., p. 155.

zti Ibid., p. 235. 
Raid in $1930 .^{27}$ Joshi gained her fame as an anti-colonial terrorist in the Meerut Conspiracy Case in the 1930s. She also took an active role in organising working class women into the nationalist movement. Joshi joined the Communist Party in the 1940 s alter her release from prison and worked actively in MARS, the AIWC and the CPI in the north-eastern city of Chittagong, one of India's largest military bases during World War $11 .^{38}$ Both strands in the AIWC, the nationalist feminist and the mass-based leftist women's movement, actively supported the reform of the Hindu personal laws and were fiercely anti-colonial. However, their strategies for alfecting this change were quite different. Nationalist feminists sought to mobilize, educate and provide for the masses of women. Leftist feminist sought to organize these peasant masses to fight for their future. Communist advocates of a mass-based women's movement sought to create a movement led and peopled by rural, peasant, working-class and middle class women.

Soma Marik offers a valuable insight about how communist women's activism differed from bourgeois nationalist women. ${ }^{29}$ She describes the CPI's 'stress on individualism' for women comrades combined with an equally strong emphasis on the collectivity of class politics. ${ }^{30}$ Marik cites her 2001 interview with the powerful communist leader, Bani Dasgupta, who described her communist subjectivity in the following language, 'We were taught that first comes our independent existence. To retain your independent existence you must learn to stand straight. You must learn to fend for yourself, to take on social responsibilities'.31

${ }^{27}$ For more on that raid, see Subodh Roy, Cbillagung slmoury Rurit: A Nemuir, New Delhi: Left Word Books, 2015.

2* Geraldine Forbes, Winten in Sholern Intia, Cambridge: Cambridge University Press, 1988. Kalpana Datta Joshi joined MARS in 1943 and was also an officeholder of AJWC in the 1940s.

ry Soma Marik, 'Breaking Through a Double Invisibility: The Communist Women ol' Bengal, 1939-1948', Critical suian Sturtien. 45 (1), 2013, pp. 79. 118.

3.l Marik, 'Breaking Through', p. 92.

${ }^{31}$ Ibid. 
The leftist movement provided the space for women to forge a political and social identity separate from that given them by their family and by the state. It was this independent identity that allowed women to be active participants in the collectivity of class politics. In other words, class politics did not merely subsume women; it relied on their independence that allowed them to act as integral to these collectivities.

Dasgupta became a powerful force in the communist women's movement and traveled widely as the secretary of the Women's International Democratic Federation to support the Afro-Asian women's movement in the 1950s and 1960s. Dasgupta learned her independence and gained the skills to shoulder 'social responsibilities', through the CPI. Nationalist women, by and large, found their political identity located within the patriarchal fold of the new nation. Communist women, on the other hand, fought against the patriarchy of the state institutions. What did self-reliance and standing straight mean for Bengali peasant women who negotiated norms of respectability differently from middle class women in rural towns and localities? Communist leaders in the Indian women's movement like Dasgupta, Manikuntala Sen and Renu Chakravartty all provide personal narratives about joining the communist movement as middle class or elite Bengali women. They describe the sexual politics of' renouncing respectable forms of women's seclusion from public life in order to become activists. For peasant women, their sexual politics revolved around the right to live without sexual coercion and to claim their own bodily autonomy in a regime where large landowners had the first and final say over their sexual availability.

ORGANISING RURAL WOMEN AND THE BENGAL FAMINE

At least three and a half million people died of starvation and disease during the Bengal famine between 1943 and 1945. Ten million people left their land in search of food. Over 900,000 families sold off their land holdings, and fifty to eighty 
percent of small landholders and sharecroppers sold oft their plough cattle. Potters, basket weavers and people from fishing communities fared even worse and were the first to lose the tools of their trades. ${ }^{32}$ These losses to the rural poor meant that forty percent of the population in rural areas became landless due to the famine. Middle and large landholders (called jotedari and zamintar, respectively) gained in all of these transactions, with the jotedari - who lived in rural areas and also acted as moneylenders - reaping the largest share of the spoils. ${ }^{35}$ Even after the immediate food shortage subsided in 1944, the devastation continued for those people stripped of the tools of their livelihoods and their land.

During the famine, peasant women faced a complete reordering of daily life as the ideologies of hierarchical care that supported the status quo in rural areas lay in tatters. ${ }^{3-1}$ The famine, in the context of the war and heightened nationalist movement, also undermined women's long-standing social constraints like purdah and other forms of women's seclusion from public life. Men abandoned or migrated away from their families in search of work. They were also among the first to die of malnutrition. Women who lost their husbands and extended families had to seek food and work for themselves and their children. During the war, the greatest call for women's work was sex work to service the men in the military along the India-Burma front, and construction work to maintain roads and infrastructure for the military. ${ }^{35}$ Mostly poor Muslim and Dalit peasant women migrated to cities, such as Comilla, Chittagong, and Kolkata and

32 Madhusree Mukerjec, Churcbill, Secref Wfar: Tbe Brithb Enpire and the Ravaging of India during IFurh Whr II, Chennai: Tranquebas Press, 2010. pp. 66.7.

${ }^{33}$ Cooper, Sbarecropping and Sbarecruppen, Struggla in Bengal, p. 133.

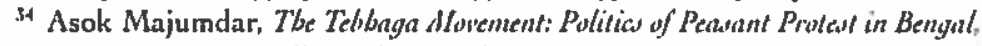
1976-1950, New Delhi: Aakar Books, 201 1, p. 225.

35 Yasmin Khan, 'Sex in an Imperial War Zone: Transnational Encounters in Second World War India", Heilury IForliseop Journal, 73 (1), 2012, pp. 240-58. 
entered brothels or worked off the streets. There is no record of whether any of these women were able to return to their localities when the famine subsided two years later. However, records of MARS and AIWC campaigns for dispossessed women's work training and homes documented the widespread displacement of women from their original families well after the famine ended. ${ }^{36}$

In May 1942, leftist women's groups created the coalitional Mabila Atma Rakitba Samiti (MARS) as a mass-based women's group to lead the fight against fascism, colonialism and deprivation. In part, it formed in response to a Soviet-led appeal in September 1941 to unite women internationally against fascism. ${ }^{37}$ Its members were largely middle class, from a range of political parties and numbered roughly two thousand. MARS activists had already begun organising among women in Kolkata's slums when the first famine victims reached the cities late in 1942. By early 1943, communist and non-communist members of MARS fanned out from the cities of Bengal to provide food relief and build shelters for dispossessed women and children in the countryside. By 1944, just two years later, MARS had 43,500 members, including many rural women, quickly becoming the largest peasant women's group in India. ${ }^{38}$ It led a coalitional campaign that linked rural organising by communist and nationalist women in a united effort to fight starvation and sex trafficking of dispossessed women and girls. They investigated women's reports of rape in peasant insurgencies against Indian landlords and British colonial officials. Additionally, they sought restitution of women into work and homes to provide new lives for women pushed into unpaid or low paid sex work by the famine. Their organising methods allowed lettist women's

Ti. Renu Chakravarty, 1980.

17 Gargi Chakravartty, 'Emergence of Mahila Atma Raksha Samiti in the Forties - Calcutta Chapter', in Tanika Sarkar and Sekhar Bandyopadhyay (eds.), Catculta: The Stormy Decaktes, New Delhi: Social Science Press, 2015, p. 179.

34 Ibid. 
groups to build a mass movement of peasant and working poor women.

The name Mahila Atma Raksha Samiti, or the Women's Self-Defence Committee, held complicated echoes of anticolonial and communal movements of the early $20^{\text {th }}$ century. 'Self-defence' in these movements could signify religiously bigoted and sexist assumptions. ${ }^{39}$ The targets of violent forms of self-defence, in a Hindu nationalist world-view, were often Muslims. Hindu men defended Hindu women's honour from Muslim men. A nationalist deployment of the idea of selfdefence imagined an independent India defended by its Indian citizens. For nationalist feminists, Indian women were part of its citizenry to be defended. In the context of leftist feminist groups of the early 1940s, 'self defence' had a nationalist resonance, but included another meaning - women actively defending their own rights and lives. Yet the complicated politics of honour in relation to sexualized violence against women and self-defence by women instigated the new political forms and strategies fostered by MARS during the famine and after.

The Soviet internationalist call for women's anti-fascist groups echoed a demand for self-defence of women's honour by women. The English language pamphlet To IVomen the IVorld Over carried speeches from the Women's Anti-Fascist conference held in Moscow, that were filled with gruesome stories of German soldiers' rape of girls and women in Germany and on battlefronts in Hungary and the Soviet Union. ${ }^{40}$ In the conference's pamphlet, Appeal to IVomen the IVorld Over, conference speakers described German soldiers' actions using the terms of women's sexual honour.

sy Samita Sen, 'Honour and Resistance: Gender, community and class in Bengal, 1920-40' in Sekhar Bandyopadhyay, Ahijit Dasgupta, and Willem can Schendel (eds.). Bengal: Cummunities, Development aml States, Delhi: Manohar, 1994, pp. 209-54.

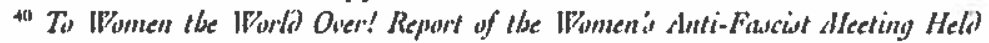
in Houcou" on Septemlier 7, 19-11, Moscow: Foreign Languages Publishing House, 194]. 
These villains have not only dishonoured hundreds of thousands of" women and girls; they have even infected them with foul diseases. How many Polish and Serbian women and girls they have driven into brothels; how many lives they have ruined; for many suicides they have caused in Poland, which they have drenched with blood! t1

The conference did not accept the stories in a passive way, their language around rape as 'dishonour' marks the women raped rather than the sexual aggressors. Their 'self-defence' ethos meant that they retold the stories in terms of women's delence of their own honour against rape and sexual violence by a fascist enemy. Earlier masculinist echoes remain in the call to action of passive women 'dishonoured' by acts of wartime rape. To be 'dishonoured' - a synonym for rape - puts the burden on the elfect of the rape on the women's bodies. There is no 'dishonour' to the men who raped the women. In the emphasis placed by the leftist conference, it is for the women to seek justice for the abjection caused by rape and forced prostitution.

Historian Soma Marik, drawing from the interviews with communist women leaders of this period, suggests another dimension to the women's fight for social or class-based goals. "The demand for women's self-detence was posed as a part of" the defence against fascism', she writes. 'As Bani Dasgupta's interview makes clear, women also had to learn to fend for themselves and self-defence was linked to social goals. Notwithstanding persistent talks about honour, the crucial shift was in the insistence that women had to learn to fend for themselves and this defence was linked to social (class) goals' ${ }^{42}$ Marik emphasizes a radical shift away from the communalist defence of women and from a nationalist view that women must be defended by the state. The former - the communalist - would typically seek recourse for Hindu women from Muslim attack;

11 Ibid., pp. 53-54.

+2 Marik, 'Breaking Through', p. 103. 
the latter - the nationalist - would seek recourse for all women from the state. The Left's approach to self-defence pushed for women to 'stand straight' - to courageously fight for greater class and social goals. ${ }^{43}$ For the Communists, women's independent political action for the greater ends of class struggle defined the contours of self-defence.

Self-defence in MARS name-atmarakstba - was a call to action, not a call for protection. MARS combined its internationalism and nationalism with local campaigns for women's self-defence. The backbone of MARS' educational work amongst working-class and peasant women meant a combination of anti-fascist solidarity with the nationalist campaign for the release of imprisoned Indian freedom fighters and fights for relief and survival. The international and even national goals came alongside local reform work to better people's daily lives. Without the latter, MARS would not have gained traction amongst its base. In its first months, MARS members focused their work in Kolkata to facilitate the fair distribution of subsidized food and cloth. Manikuntala Sen, a member of the CPI since the late 1930s, was a founding member of MARS. She recounted touring Bengal at this time '(p)reaching anti-fascism, making speeches, and establishing mahila samitis (women's groups)'. ${ }^{44}$ Most MARS members, however, did not tour Bengal and had little contact with rural women. The MARS groups established in the countryside were few and isolated, mainly linked to locations in northern and eastern Bengal that had nari samitur (women's groups) which were part of active communist and peasant organising elforts. The famine that spread across Bengal in the early months of 1943 changed MARS completely.

In the first months after the formation of MARS, members like Manikuntala Sen, Ela Reid and Renu Chakravartty ran self-defence and first aid classes for middle class urban women

As. Ibid.

14 Manikuntala Sen, In Searcb of Freedont: Ant Unfintubed Journey, Kolkata: Stree Press, 2001, p. 66. 
to prepare for a military attack on the city. Their international anti-fascist demand sought the defence of India trom attack by fascist military forces, a daunting task since the most highly trained Indian troops were stationed in the Mediterranean, with troops in Bengal almost wholly under-resourced by the British who feared an internal uprising before a Japanese attack. ${ }^{45}$ The war's progress from the South China Sea to Singapore and then up the Malaysian countryside altered British calculations. Japanese troops occupied Burma in 1942, amassed their forces along the border with Bengal. Japanese aircraft began bombing raids on Kolkata and the Bengali countryside that same year. The Arakan front, as the border between India and Burma was called, made Bengal the station for hundreds of thousands of troops from Australia, England, North Africa and India who had no modern weaponry and little training. ${ }^{46}$ The British fear of moving effective weapons to India from other theatres of war took precedence over the threat of invasion by the Japanese. ${ }^{47}$ American and Chinese forces joined the battle after the Japanese successes in Burma, and US troops built a military infrastructure within Bengal.

The spectrum of Indian political forces demanded that the British imperialists release the imprisoned independence fighters. MARS took this position as well. They argued that the national leaders and the political activists would galvanize the anti-colonial movement against fascist aggression. Heightened communal tension amidst the starvation and fear drew from MARS a principled attempt to create unity amongst all Indian forces. Manikuntala Sen recounted how MARS sought to unite 'the Hindus and the Muslims and people of all denominations, the Congress, the non-Congress, for the prisoners' release

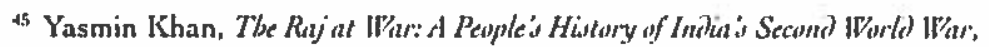
Gurgaon, Haryana: Random House India, 2015.

tii Ibid.

t7 Muteries, Churbill's Secret Whar, pp. 59-61. 
campaign'. ${ }^{48}$ The campaign to release political prisoners was used by MARS as a way to create a broad unity - the unity of all Indians in what they imagined would be an independent and united (secular) Indian nation.

By 1943, the famine had devastated Bengal. MARS' objectives changed. Renu Chakravarty, another communist founder of MARS, defined the new objective as 'delence of the people from starvation and death: ${ }^{49}$ Manikuntala Sen described the work by MARS members in Kolkata:

Dividing time into shifts, some of us would stay near the queues. Procurers from the sex trade would hover around young women who had to be saf'eguarded. Some women would give birth while they waited and they would have to be looked after. Sometimes a woman would remain in the queue with a dead child in her lap, refusing to let go of her place; there were many such incredible sights. Day and night, our workers didn't have a spare moment. ${ }^{\text {jit }}$

Large landowners hoarded grain as prices for rice and wheat tripled and quadrupled in the almost empty markets. The Japanese occupation of Burma shut down the usual importation of rice from Burma and Thailand. The British government bought up food staples at sharply higher prices to feed its soldiers along the trontlines of India, and exported the rest to troops around the world. In 1941. Bengal imported 296,000 tons of rice, yet by 1942 the flow had reversed to an exported 185,000 tons of rice." The famine finally gained international coverage by the summer of 1943, when finally the British-controlled press began to report on the crisis. 'Mass of Walking Skeletons; Conditions in Rural Bengal', read one early headline on the front page of

\footnotetext{
4" Manikuntala Sen, In Search of Freedum, p. 77.

4) Renu Chalsravartty, 1980, p. 23.

so Manikuntala Sen, In Searb of Freelym, p. 71.

"\$1 Mukerjec, Churcbill', Secret War, p. 68.
} 
the Hindustan Timer. ${ }^{52}$ Still, Churchill turned down relief food supplies offered from the United States, citing the dangers of the waters in the Bay of Bengal. His response to a plea from the government in Delhi for food supplies was to ask why Gandhi hadn't died yet. ${ }^{.55}$

Kanak Mukherjee, a communist and founding member of MARS, traveled the breadth of rural Bengal and wrote frequently about peasant women during the famine. In 1944, she raised the alarm when the paltry government food and work relief ended almost as soon as it began. Mukherjee's article was titled, 'Our Famine-Homeless Sisters' Plight: Bengal Government's Work Houses Closing Down'. ${ }^{-4}$ Her article reported that the government workhouses were merely food relief kitchens serving tood rather than providing work training to women. She emphasized the real demand of jobs for the six and a half million displaced and starving peasant women. Rural MARS groups took up the crises of the colonial power's exploitative and neglectful governance. They started canteens for the starving and homes for destitute women and children. They provided relief with their social reformist and nationalist feminist allies. MARS also built the sinews for a rural mass movement of peasant women. They held organising schools for middle-class and peasant women that lasted from a week to a month to train new members about how to hold regular meetings, form demands and run campaigns. ${ }^{\text {ss }}$

During the famine, middle class MARS activists in the countryside saw firsthand the long-standing sexual vulnerability of rural, landless, adivasi and Dalit women at the hands of jotedar

52 'Mass of Walking Skeletons; Conditions in Rural Bengal', The Hindustan Times, November 6, 1943.

st Mukerjee, Cburchill's Secret IVir, p. 235.

it Kanak Mukherjee, 'Our Famine-Homeless Sisters' Plight: Bengal Government's Work Houses Closing Down', Pesple's Nisr, September 1944, p. 9.

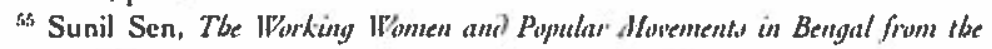
Ganlbi Ena to /be Present Day. Kolkata: K. P. Bagchi \& Co., 1945, pp. $31-33$. 
and zamindar landholders. ${ }^{56}$ Women had been trafficked as sex workers for the military, large landholders and moneylenders. MARS led the fight against the trafficking that had become commonplace in rural Bengal. Members of MARS held an open rally in May 1944 that demanded 'stringent measures for punishing those who traded in women's flesh and also measures for the rehabilitation of such women in society'. ${ }^{57}$ Anti-fascism among peasant women during the war in Bengal and Burma along the Arakan front meant a fight against the traffickers of women who were often land holders and money lenders, as well as the hundreds of thousands of Allied soldiers stationed in Bengal. 58

On 6 January 1945 MARS convened a coalitional meeting to end women's prostitution due to tamine conditions. They partnered with the AIWC and ten additional women's organizations. On the one side, MARS and AIWC (along with other women's groups) wanted trafficking to be seen as a criminal offense. On the other, MARS tought for the creation of jobs and housing for trafficked women so that they could be come selfsulficient. ${ }^{59}$ Through these goals, MARS leaders sought to build self-respect, economic self-sulficiency, and even social respect for trafficked women. They countered the dominant terms of middle class charity and short-term government relief, In the process, they created networks of rural women organizers where few had existed before.

Nationalist feminists utilized starkly different language from leftist feminists. Sarojini Naidu spoke to the 1945 meeting using the unambiguous language of women's honour. 'As long as one woman is defiled, as long as a man's lust devours another woman, as long as the stronger sex has the power to get hold

Sto Majumdar, $2011,224$.

57 Chakravartty, 1980, p. 55.

5N Chakravartty, 1980, 41.

59 Gargi Chakravarty, 'Emergence of Mahila Atma Raksha Samiti in the Forties', p. 192. 
of hundreds of shelterless women in their clutches, no woman's honour is safe'. ${ }^{60}$ The strongly moral tones of women's weakness and vulnerability in Naidu's speech framed common notions of women's honour by focusing on the actions of men who 'defiled' and 'devoured' women. Naidu sought to arouse national sympathy for women who turned themselves and their children to sex work during the famine. She placed the onus of shame on the men who exploited their vulnerability. Her condemnation of starving women's turn to sex work, however, still used the dominant framework of shame and honour - and of the need for the state to protect the women.

Leftist feminists deployed a language of a gendered political economy to describe women's famine-based sex work. In December 1945, at the AIWC national conference, Renu Chakravartty submitted her report about the new, endemic quality of trafficking in Bengal after the famine. She listed 'economic stress and food shortage' as a primary reason for husbands selling their wives to traffickers and women selling themselves. She added two additional factors rarely mentioned in mainstream reports about the vast increase in prostitution. 'A large percentage of the peasantry sold their lands and the poorest classes sold their implements of production, such as fishing nets, handlooms etc. in order to buy food, and were therefore left without any means or equipment for earning their livelihood'." She provided a materialist analysis of who turned to sex work for survival. Dalit and adivasi women relied on fishing, handicratts and sharecropping, working in conditions of the greatest insecurity for the lowest wages. She ends with her last explanation, '( $t$ )he presence of a large army always tends to encourage immoral traffic'. ${ }^{62}$ She gives three suggestions for AIWC's future work: first, create places to rebuild the tools of

1int Quoted in Chakravartty, 1980, 69.

"il AIWC. 'Annual Report of Member-in-Charge of Social Section, 1945", Hansa Mehta papers, Subject file 7, NMML.

"i: Ibid. 
trade, like looms and fishing nets; second, gather information about and prosecute abuses in government-run homes; third, demand the "enactment of a law by which traffickers can be promptly and heavily punished'.63 Strikingly, in this report Chakravartty did not attempt to explain or excuse women's actions, but explained the social and political context for those actions. Even in her use of 'immoral traffic', a common term about women's sexual honour, Chakravartty referred to sex traffrcking of women rather than women's sex work. Wornen's economic self-sulficiency was a key demand in the MARS campaign against sex trafficking. They sought women's access to paid work other than sex work, primarily through homebased labour in the handicraft industry. ${ }^{64}$

The Left activists in MARS played down the language of honour and dishonour. This would not allow them to accomplish their main task - to provide space to the working-class and peasant women to become independent political actors for collective struggle. The barriers for women to forge this road should not be underestimated. 'Poor peasant women', wrote oral historian Adrienne Cooper, 'were involved with MARS generally as recipients of charity or mobilized to support the kisan sabhas in demonstrations or at meetings . . . Most women faced opposition trom family, village or community for even minor involvement in such activities, because in itself this challenged women's traditional roles' ${ }^{65}$ To become independent meant to break from the idea of 'traditional roles', a process that required time and patience. The national movement allowed women to enter the political domain, and it was this opening that allowed MARS to draw rural women into their struggle. But MARS wanted more than merely to suborn women to the national movement. They wanted women to have no less than full participation. As the MARS 1944 conference statement put

is lbid.

it Cooper, Sharecropping and Sbarecrupperi' Struggles in Bengal, pp. 270-72.

is Ibid, p. 270. 
it, "To stop the rot in society and to re-establish the shelterless and destitute women in social life is one of the prime tasks in defence of the dignity of the women of Bengal'.66

\section{COMMUNISTS IN AIWC AND THE COLD WAR}

The end of the Second World War in the colonies of Europe and Japan did not ease the battle in the Astan sector. The British, Australian, North African and American troops stationed in Bengal since 1942 mostly departed by 1946. The 'war' now moved from one against the Japanese fascists to against the imperialists. 'Self-Defence' groups shifted their focus to the resistance against British colonialism. The British sensed that their control over India was over. For a brief window, the communists and anti-colonial nationalist women's movement in India stood politically united. This was the high-point of national unity. Disagreements over how active women should be in the independent nation-state divided the bourgeois nationalists from the leftists. The dominant Indian Congress Party and to a lesser degree the Muslim League refused to cede meaningful power to the largely illiterate rural masses of people or their demands. Abani Lahiri, a Communist Party member, was a key peasant organizer during the Tebhaga movement. He remarked in his memoir that, 'the influence of feudal elements on the national movement in our country not only failed to attract the peasants to the common national plattorm, it pushed them away. ${ }^{\prime 67}$

In 1945, British officials sent Indian troops into Burma and Malaysia to suppress nationalist aspirations that manifested themselves throughout the region (this mirrored the return of French troops into Indo-China and the Dutch to Indonesia, on the other side of South-East Asia). Asian women's movements pushed back against this renewed imperialist thrust. That year, the AIWC meeting denounced the use of Indian troops in Burma

(a) Conlerence statement cited in Chakravartty, 1980, p. 55.

t7 Abani Lahiri, Parturar Rewolt of the Rural Prou in Bengal: Mesmoin of a Csmmumul Actiolt, Kotkata: Seagull Books, 2001, p. 78. 
and Malaya. The meeting also took a strong position against the use of Indian troops to support the Dutch in Indonesia and the French in Vietnam. AIWC's roots in the anti-colonial struggle had been dug deep, and now strengthened by their experience of organising a mass movement during the war. The solidarity did not go in one direction. In 1946, AIWC's journal Rubni published an appeal for pan-Asian solidarity by the Singapore Women's Federation in their shared anti-colonial struggles. It began, ' $(t)$ he people of India and Malaya have suffered severe oppression and are fighting for the ideals of human dignity and political liberty. We have to join hands together to break the chain of oppression and to be able to effectuate our ideals on a brighter road'. ${ }^{68}$ The Singapore Women's Federation, like AIWC, had been an important component of the Malaysian national movement and - in late 1946 - would be a constituent of the All-Malaya Council of Joint Action.

For the anti-fascist popular front of MARS and the leftist women's movement in Asia more widely, the pan-Asian women's movement strengthened their anti-imperialist alliance with women's groups in Europe, the United States, and the USSR through a common commitment to anti-fascism. ${ }^{69}$ Leftist and anti-colonial women's groups celebrated the inauguration of the WIDF in Paris, France at the end of 1945. Four women from the Indian women's movement attended this opening conference: Vidya Kanuga (later known as Vidya Munsi), a member of the All India Students Federation who later joined the Communist Party; Ela Reid, a politically non-affiliated American woman who was a founding member of MARS; Jai Kishore Handoo, a member of the Women's Committee of India League in London (affiliated to the Congress Party) authorized to represent the AIWC; and Roshan Barber from the India League's London Office.

\footnotetext{
tis 'Singapore Women's Federation', Raubni 1 (5). June 1946. p. 55.

til' Armstrong, 'Bulore Bandung'.
} 
Reid and Handoo particularly fought to widen the ethics of anti-fascism at the meeting to include the ongoing struggles against colonialism. Handoo addressed European women directly in the discussions. She wanted them to mobilize public opinion in favour of freedom and democracy, and to proclaim your desire to see established in all colonial countries, especially in India . . personally struggling, suffering imprisonment, machine gun fire by air, whipping and other humiliations too numerous to enumerate here.$^{\prime 0}$ The fall of Germany, Italy and Japan in 1945, the Indian delegates argued, did not herald the defeat of fascism. Fascism lived in the imperial subjugation of peoples across the globe. After a debate among the participants, WIDF members agreed to add a condemnation of imperialism to their foundational principles.

Avabai Mehta celebrated WIDF's embrace of anticolonialism in her Rashi article called 'International Contacts of the AIWC'. She contrasted the 1945 board meeting held by the International Alliance of Women (IAW) to WIDF's founding meeting unfavorably due to the former's 'timidity to endorse the AIWC resolution for the liberation of all peoples of the world'. ${ }^{\prime \prime}$ Handoo was also AIWC's representative at the IAW conference held in Geneva, Switzerland. Kamaladevi Chattopadhyay wrote a letter that clearly stated the AIWC position, namely that the 'termination of the war will not bring peace unless it leads to the abolition of imperialism and liberates all enslaved countries including India'. ${ }^{72}$ Yet even with Chattopadhyay's written statement to the IAW leadership, Handoo failed to gain an explicit condemnation of colonialism. In the face of this intransience, the AIWC still faced pressure from the IAW to

71 'International Congress of Women founding meeting of WIDF, November 26-December 1. 1945:

7t Avabai Mehta, International Contacts of the AIWC', Ruthni 1 (3), April 1946. p. 49.

T2 Quoted in the anonymous report, '18th Conference in Hyderabad', Rarlini 1 (1), February 1946, p. 28. 
repudiate leltist international groups, particularly the WIDF.

The president of the IAW, Margaret Corbett Ashby, also attended the founding conference of WIDF in 1945. In a typed note she judged the conference 'a disappointment because the communists over-played their hand'. ${ }^{73}$ She wrote a deeply unfavorable assessment of the conference, a copy of which she sent to Hansa Mehta, the president of the AIWC. Ashby argued that WIDF's conference's focus on anti-fascism produced a fleeting popular front among the delegates from over 35 countries. 'If you are flattened under an immense weight, unable to move or speak and past breathing, and then some large person removes the weight, grips your arm, stands you on your feet and with still fast grip walks you along, you are only conscious of freedom and release. ${ }^{74}$ She predicted a swift end to this unity. which had been created by the fear of fascism's resurgence, once their gratitude to the Soviet Union's Red Army had abated. To the IAW chapters and groups affiliated with IAW, Ashby advocated a strategic solidarity. 'I suggest that the alliance must continue as a teminist organization on friendly terms with this new organization which has reached masses of women we failed to arouse ${ }^{75}$ While not a mass organization, the AIWC was one anti-colonial women's group publicly unimpressed with the IAW position on colonialism. Nevertheless, AIWC maintained old ties with the Alliance, and also sent delegates to WIDF meetings for two years.

Ashby waited less than a year after the 1945 Geneva board meeting to invite Mehta to join IAW's executive committee. Her goal was the same: to reach out to, in her words, the 'masses of women we failed to arouse'. In a hand-written letter addressed to Mehta, Ashby wrote of Mehta's importance as IAW attempted to build a constellation of pan-Asian women's groups. Ashby knew

is Margaret Corbett Ashby, 'Report on Paris Conference, 26 November 1945'. Hansa Mehta Papers, Subject File 7, NMML.

it lbid.

75 lbid. 
that IAW would need the masses, but was politically averse to the groups that had built mass memberships. Ashby needed Mehta to be their representative in Asia, a continent that now seemed essential to IAW's aims. 'We do need you badly to keep us in touch not only with India but also with the other countries of Asia where the women are becoming increasingly aware of their citizen responsibilities. ${ }^{76}$ If an Asian leader came on board the IAW, it would give legitimacy to this largely Western group. 'We do feel it would be of far greater influence if you could sign letters asking the women's associations to join up', Ashby wrote, 'rather than if they get only Dr. Rydh's signature or mine' ${ }^{77}$ Ashby was British, while Hanna Rydh, IAW's Vice President, was Swedish. Hansa Mehta, being Indian, would give IAW credibility in Asia.

Francesca De Haan has reminded scholars of the anticommunist stakes of international organizations like the IAW in the Cold War. ${ }^{78}$ The IAW was not politically neutral. It saw its role as being a defender of the Western (capitalist) world order. The enemy, for the IAW, was the communist threat. The anticommunism within the AIWC, however, did not mirror the anticommunism of IAW. What divided them was their understanding of colonialism. AIWC took an anti-colonial position, while IAW was chary to do so. Within the AIWC, as well, tensions remained between the communist women and the bourgeois nationalists. Communist women pushed for a more controntational stance against the Indian state, while bourgeois nationalists wanted a more generous attitude towards it. The conflict over communism in the AIWC, however, was not simply about abstract principles nor was it uniform. Communist members in the AIWC - such

76 Letter to Hansa Mehta, Margaret Corbett Ashby, dated 7 September 1946, Hansa Mehta papers, Subject file 6, NMML.

77 lbid.

i* Francesca de Faan, 'Continuing Cold War Paradigms in Western Historiography of Transnational Women's Organizations: The Case of the Women's International Democratic Women's Association'. W'ometr, Hinliny Relieur 19 (4), 2010, pp. 547-73. 
as Romesh Perin Chandra in Punjab, Renu Chakravartty in Bengal and Hajrah Begum in Uttar Pradesh - worked alongside their non-communist comrades to create regional groups that had a left character but were formally popular front groups. Bengal's MARS and Punjab's Women's Self-Defence League are good examples of the fruit of this joint work. At no point did the communist women not try to organize women into AIWC and to push the AIWC to relief work for those in acute distress. The work drew women of all persuasions to support it - in 1944, Rameshwari Nehru - cousin of Jawaharlal Nehru - supported the Punjab Women's Defence League, when its thousand working-class and peasant members merged with the AIWC. ${ }^{\text {ig }}$ The character of the AIWC was far to the left, therefore, of that of the IAW.

Sometimes the activities of regional leftist women's groups overlapped with AIWC unhappily. During the early months of 1947, a flurry of contentious letters by Kalpana Datta Joshi, a prominent member of the CPI, and Nellie Sen Gupta, a powertul member of the Congress Party and first president of MARS, were sent from Chittagong in the eastern part of Bengal to Indira Maydeo, the general secretary of AIWC. The issue before them was whether Joshi's membership in the Communist Party soured her work for AIWC. Between March and July of 1947, Joshi and Gupta debated the status of Joshi's membership in AIWC and the Communist Party - could she remain a member of both ${ }^{80}$ By the end of the year, a letter from Nellie Sen Gupta and Asoka Gupta settled the matter: Joshi was out. They took over as the new AIWC leaders of the renamed branch Chattagram Sabar Nari Sammelan. ${ }^{81}$ Joshi left

7s Ahmad interview, 1994, NMML.

st" Letters to Indira Maydeo, general secretary of AIWC, by both Nelfie Sen Gupta and Kalpana Joshi dated 15 March 1947, 26 July 1947 and 31 July 1947, AIWC Branch reports, file 65, NMML.

"I Letter signed by Nellie Sen Gupta and Asoka Gupta, 22 December 1947. AIWC Branch reports, file 65, NMML. 
the AIWC soon afterwards to concentrate on organising women into MARS, the CPI, and the peasant movement. ${ }^{82}$

The debate over the role of communist women in the AIWC became increasingly virulent as India's independence neared. In January 1946, Kitty Shiva Rao - an olfice holder and member of the AIWC Standing Committee - wrote to Rajkumari Amrit Kaur - a Congress leader and former president of the AIWC. Shiva Rao also sent the letter to AlWC's current president Hansa Mehta. "The reason why I am writing this letter to you is, that I feel extremely disturbed and apprehensive with regard to the trend of things in the Conference concerning the Communist problem', she wrote. ${ }^{83}$ She described her particular discomfort with Hajrah Begum's role as editor of AIWC's Hindi-Urdu magazine Roulmi. 'However many promises these people may give, surely their first loyalty is to their party and a magazine must be a sore temptation for propaganda purposes". ${ }^{\text {s4 }}$

Women like Hajrah Begum who was a long-term office holder for AIWC, and member of the Communist Party troubled the founding tenets of AIWC as a social reform organization. Hajrah Begum and other communist members pushed the AIWC to confront the abuses of power by princely regimes like the Nizam of Hyderabad and large landholding zamindars. They sought to sharpen AIWC's class politics in favour of the poor and working class, not simply to maintain its nationalist bona

N2 Tension between the Congress and the Communists goes back to the 1920s. This was a debate that had a recurrent history. In 1944, the Communist leader P.C. Joshi and Congress luader Mahatma Gandhi corresponded on just this dispute - whether CPI members could be relied upon in the Congress. This was published in People i H'ar between August and October 1944 (and Jater collected as Comrespombence Befurew dfabalma Gandli and P.C. Jubisi, Bombay: People's Publishing House, 1945). Joshi assessed the debate in People' IFar in November (later published as a pamphlet - P.C. Joshi, Congress and Communits, Bombay: People's Publishing House, December 1944).

"33 Letter to Raj Kumari by Kitty Shiva Rao, dated 3 January 1946, Hansa Mehta papers, Subject File 6, NMML.

k-1 Ibid. 
fides. As editor of Robmi, Hajrah Begum published accounts of peasant and working class campaigns against large landholders and princes in states like Andhra, Maharashtra, Bengal and the Punjab. Reporting on these powerful struggles led by peasants was not sufficient to depose Hajrah Begum from the editor's chair. It was Hajrah Begum's open support and involvement in these struggles that raised Shiva Rao's hackles.

In AIWC, the dispute would take on a practical form. AIWC planned to lower its membership dues so that all women could join the organization. This would mean that more workingclass and peasant women would join the AIWC, and they might eventually be able to shape AIWC's agenda and stance. A test site for the problem of letting in communists and peasant women was in the Guntur-Bezwada area of Andhra. Konda Parvati, daughter of Congress leader Konda Venkatappaiah, prevented the local communist women from entry into the Guntur Ladies Club. One of the communists - Dr. K. Atchamamba - wrote to the AIWC a few weeks before the dispute between Hajrah Begum and Shiva Rao. Dr. Atchamamba had organized an AIWC club with 25,000 members in Bezwada - across two hundred and fifty villages and seven large regions. ${ }^{85}$ Konda Parvati did not want these women to be alfiliated to the AIWC. Atchamamba wrote to AIWC's General Secretary Kulsum Sayani about Konda Parvati's refusal (the letter was also sent to Hansa Mehta). 'We appreciate what you say regarding the enrollment of new members to our Sandham on the present basis', wrote Atchamamba, 'but unfortunately there is no change in the attitude of Srimati Konda Parvati. She is still of the view that our Sangham is not affiliated in spite of the resolution of

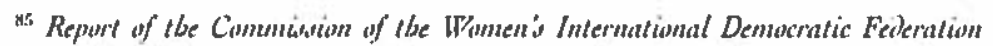

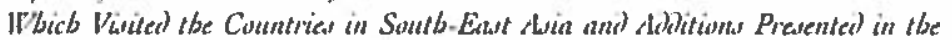

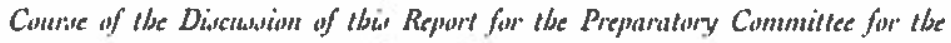

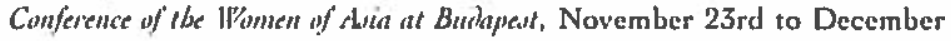
2nd, 1948, p. 25. 
the S.C. [Standing Committee]: ${ }^{86}$ Konda Parvati, like Shiva Rao, worried that the new members enrolled by the communists would threaten the old order within the AlWC. These new members came with little literacy and from poverty - they were drawn to the struggles through issues of exploitation of their labour and land. It was the communists who drew them in. It was not that the AIWC leadership did not want these women in the AIWC. They merely wanted them as passive members, not - as the communists hoped - as leaders in their own right.

Atchamamba directly answered the anti-communism of Konda Parvati's refusal to admit the group into AIWC. 'Our anxiety is not to 'capture' any organization, or even secure any positions or offices in any of the committees', she wrote. 'We are anxious to work as a part of the All-India and the Provincial organization which is necessary for building up a strong all-Indiawide women's organization'. The Bezwada group, Atchamamba wrote, is 'eager to have organizational links with the AIWC, so that we may enrich the AIWC with our work and support and get gained (sic) by the guidance on the several problems concerning the women of India'. ${ }^{87}$ From the point of view of the communists, a secular popular front for women was essential; this is what AIWC represented. Women such as Atchamamba worked amongst working-class and peasant women to bring them into the AIWC so as to widen its mission to include their issues. Atchamamba and Hajrah Begum knew that drawing in large numbers of peasant women and working-class women as leaders in the AIWC would certainly change the character and content of the AIWC. This is what worried Konda Parvati and Shiva Rao.

Shiva Rao's observation about the membership fight in Guntur-Bezwada avoided mention of the stark conditions that faced women in the dominion of the Nizam of Hyderabad. The

Mij Letter to Kulsum Sayani, by K. Atchamamba, 16 June 1945, Hansa Mehta papers, Subject file 7, NMML.

k? Ibid. 
Telangana peasant uprising began in 1946, while in the coastal regions of the state the 1948 scale violence was previewed. ${ }^{88}$ There is something bloodless about Shiva Rao's report, where she merely writes of the number of women who joined the AIWC unit. "The first number mentioned, I believe, was 19,000 , then it came to 10,000 and when the Sural S.C. questioned this figure they finally enrolled 2,500. ${ }^{\circ 9}$ Shiva Rao worried that the communists had taken over the AIWC, not that the communists and other women tried to build the AIWC in times of great turmoil in the region.

The fight against the communists in the AIWC led to an inevitable end - the restriction of membership policies. This was the turning point for the left inside the AIWC. Hajrah Begurn remembered the conflict in blunt terms. AIWC members, she said, 'did not care for the common people. ${ }^{90}$ Manikuntala Sen in her memoir gave another reason for the closed doors of AIWC. 'They thought that if we opened the association to ordinary women, their leadership would be threatened, and were suspicious that perhaps we would try to turn the association into a Communist one'. ${ }^{91}$ The mass politics of communism was embedded in debates about increasing or limiting member numbers in the AIWC since its communist members actively pushed for lower dues and more members. Those numbers, whether of dues or members, implicitly raised much more substantive issues of poor, rural and urban women's politics. Fairer wages, childcare, access to property, dowry eradication, and the right to better lives, were all communist issues in the 1940 s; they were also largely peasant women's issues.

* Padmaja Naidu, Police Atrocities on Women in Flyderabad State, mimeograph, n.d., Hansa Mehta papers, Subject file 6. NMML and P. Sundarayya, Telegana People's Straggle and /w Leswon, New Delhi: CPI-M, 1972.

"99 Letter to Kulsum Sayani. by K. Atchamamba, 16 June 1945. Hansa Mehta papers, Subject file 7, NMML.

4h Hajrah Begum Ahmad interview, 1994, NMML.

91 Manikuntala Sen, In Searcb of Freedom, p. 56. 
Hansa Mehta's measured response to Shiva Rao urged her to watch Hajrah Begum's actions as the Rorloni editor, and only remove her from the post if she put what Mehta called 'objectionable materials' into the magazine. She also reiterated her commitment to an inclusive AIWC,

We must have laith in our colleagues until they have betrayed it. The AIWC is neither for the Congress women nor for the Communists. We wish to unite all women on certain common issues viz on problems that allect women, their status and position in society. I believe the time has come when we must define it clearly. I would, therefore, not like the AIWC to be made into a political cock-pit and lorget the real issue."

During the tumultuous year of her presidency, Mehta persevered in her assessment. Her advice to the incoming president in her speech at the AIWC conference held in December of 1946 reiterated her advice to the incoming president, Dhavanti Rama Rao,

The duty of our movement is to unite the women of India, and through them the women of the world ... I hope our new President will see that our little boat does not lounder on the rocks of this party or that party, that it does not founder on the rocks of disunity; 1 hope this Conlerence will remain a uniting lorce and show what the women of the world can do to bring about peace and unity. ${ }^{\text {93 }}$

The symbolic issue was the cost of AIWC membership_but

"2 Letter to Kitty Shiva Rao, by Hansa Mehta, dated January 16, 1946. Hansa Mehta papers, Subject File 6, NMML.

"3. Hansa Mehta, 'Address by Mrs. Hansa Mehta on handing over the post of President to Lady Rama Rao at the opening session on Saturday, 28th December, 1946", Hansa Mehta papers, Second Installment, Speeches and Articles, \#4, NMML. 
the symbolism held a real significance. ${ }^{94}$ With more affordable dues, AIWC could become a mass-based rather than an elite women's organization. In December 1945, at the Hyderabad conference, AIWC finally endorsed the independence movement in India and anti-colonial movements around the world. ${ }^{95}$ State feminists and communist women gained a long-shared goal in shilting the organization towards an overtly political stance. Yet the class character of these politics was not wholly aligned. By early 1947, AIWC decided to sever all ties to WIDF. Hajrah Begum described how AIWC's leadership worried that joining WIDF would 'support world communist women's movement. So they did not agree, then we decided to affiliate on our own'." AIWC's turn away from a mass-based, peasant women's movement was not absolute. In April 1947, Kamaladevi Chattopadhyay published an article in Rosbni that said AIWC must 'build membership among rural, peasant and poor women', and 'rebuild society, not focus on preventive measures'.97

Anti-communism solidified within AIWC by 1948, though its own assessment of this shift is ambivalent. An editorial in Roubmi described the turn somberly:

Three months ago provincial governments started the roundup of' communist workers and although some of them were our members we deliberately did not comment on the governments' action as we were not aware of the liull scope of their complicity in subversive actions, especially these days when anything which threatens the stability of our administration has to be viewed very seriously indeed. ${ }^{\text {wN }}$

yefist members sought to lower dues from 3 rupees to 4 annas (one quarter of a rupee).

1.: All India Women's Conference Meets: Demands Immediate Indian Freedom:. Pesplei, ITw 4 (31), 27 January 1946, pp. 10, 12.

wh Ahmad intervitw, 1994, NMML.

"Kamaladevi Chatopadhyay, "The Task Before the All India Women's Conlerence', Rashini 2 (3), April 1947, p. 52.

** 'Civil Liberties in Danger', Ruthri 3 (6), July 1948, p. 3. 
The alliance between leftist and nationalist members within the AIWC faced an abrupt end even before India's formal independence. The conflict cannot be framed through an abstraction of communism versus nationalism however. Instead, the coalitional politics within the big tent of the AIWC shattered over the issue of admitting working class and peasant women as activists on their own terms. The class politics of gender, rather than capitalism versus socialism, split the organization's cross-political unity. Internationally, MARS joined the leftist internationalist group WIDF, and AIWC ultimately joined the IAW. In international Cold War terms, their politics were oppositional as communist/anti-communist, but their histories of cross-membership and political collaboration in the anticolonial movement tell a more complicated story.

\section{PEASANT WOMEN'S SUBJECTIVITY AND}

\section{THE TEBHAGA MOVEMENT 1946-7}

The archival traces of peasant women's organising in India are relatively scant: eyewitness accounts by sympathizers and activists, interviews, second-hand reports, movement songs, are the few visible traces of their demands that remain in the public record. Peasant women's militancy in the eastern state of Bengal was only one epicenter of the radical peasant women's movement in India. The activism of Bengali peasant women gained coherence and visibility during the Tebhaga fight (a name that translates to 'Two-Thirds') that lasted for a little over two years between 1946 and $1948 .{ }^{99}$ The Tebhaga movement refers to the farmers' central demand: that sharecroppers and tenant farmers should own a greater share of their crops, that is, two-thirds instead of the customary one-half (or less). Peasant women from Tebhaga struggles across Bengal are remembered as the most daring activists, who were frequently shot, beaten

"Wusters. Womes in tbe Tehbagn Uprising. 
or raped for their militancy. ${ }^{100}$ In the autonomous, peasantcontrolled zones of Bengal that emerged during Tebhaga, these women also sought equality within their relationships with peasant men through demands for shared access to land, wages and crops harvested, and the right to familial relationships free from violence. ${ }^{101}$ As yet we have no histories that explore how peasant women's activism in Bengal shifted so radically over the ten years between 1936 and 1946 . We do have testimonies about the social changes towards greater gender equity wrought by their activism during Tebhaga. ${ }^{102}$

In Bengal, the AIWC-supported, and MARS-run campaign against sex trafficking in the context of the Bengal famine portended the ripple effects in cultural and political movements to come. Perhaps most well known in the radical politics of postwar Bengal, the Tebhaga or Two-Thirds movement from 1946 to 1947 emerged on the heels of the Bengal famine. Procommunist peasant activists, large numbers of them women, fought to keep two-thirds of the grain crop for tenants and sharecroppers who worked the land rather than only half the crop. One enthusiastic observer, a Kolkata university student named Somnath Hore (later a famous sculptor), recounted a speech he listened to by a peasant organizer named Dinesha.

No use creeping into your shells like tortoises every time you see a rich man. Start walking with your heads held high. The rich say that we are dancing like whores to the refrains of tebhaga. What 1 want to know is, who made whores of us anyway? And having turned us into whores, why does it hurt them to see us dance? Let the rich say what they want, we are going to harvest the rice and have the tebhaga. ${ }^{103}$

1001 Lahiri, Pituturar Revolt of tbe Rurnl Parne in Bengal.

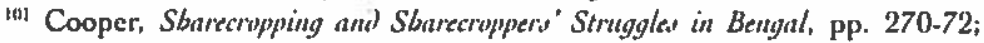
Majumdar, The Telbugn Hovenent, pp. 224-25.

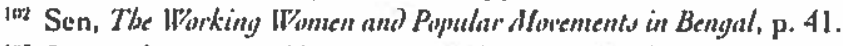

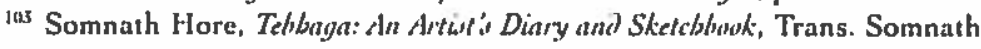


The peasant organizer Dinesha's speech rejects the usual language of a woman's and her community's dishonour embodied by the whore. Instead, the whore embodies a consequence of power relations that beggars the many in the interests of the powerful few. Dinesha's speech usurps the image of the dance girl's performance as a prostituted form of entertainment, one bought and paid for by rich men. 'Why', he asks rhetorically, 'does it hurt them to see us dance?' He turns the common sexualized and misogynist slur of feminising anti-communism on its head. The peasants' dance is the dance of revolutionary change, one that tramples on traditions of rural power. Rather than accept the normative relations of hierarchy and control, the dance girl is the peasant rebel who must dance in order to change the system. Dishonour and the embodied vulnerability of womanhood could now be configured as a weapon for the Tebhaga movement rather than solely a source of shame or dishonour for women and their communities.

The story about a speech given during the Tebhaga movement, in Dinajpur, one of its most militant localities of Bengal allows a glimpse into the radical changes of social mores for women's behaviour after the end of the Second World War, alter the abatement of the Bengal famine and on the cusp of the Cold War. In the 1980s, Adrienne Cooper collected an impressive number of interviews with women and men active in the Tebhaga movement. She noted a sea change in peasant women's organising before and after the famine-from a relative passivity in MARS campaigns to the frontline electricity of the Tebhaga struggle. 'At tebhaga meetings, women were encouraged to participate in the movement . . Poor peasant women participated in meetings and demonstrations, were in delegations to landlords and occasionally members of tebhaga committees ... However women's militancy was remembered mostly because of their actions to resist arrests, when they

Zutshi, Kolkata: Seagull Books, 1990. 
displayed incredible courage, initiative and heroism in rescuing people'. ${ }^{104}$ In this context, the demands by women active in autonomously-run peasant zones called tebbaga claka that emerged from tebhaga anti-landlord struggles gain clarity. Women used social boycotts to punish violent men, and demand equal shares to their crops.

A leading communist organizer in the peasant movement, Abani Lahiri recounted in his memoir that the most active women during the Tebhaga movement came from adivasi (indigenous) and Dalit households - the same landless households hardest hit by the Bengal famine, the same women and girls most likely to be trafficked into the war-fueled sex industry. ${ }^{105}$ Yet they were not alone as leaders. Even some women from peasant families who owned small amounts of land participated actively in Tebhaga. Peasant women practiced courage in their fight against landowners and their home-grown armies. They became integral forces in a collectivity unsegregated by gender with other landless sharecroppers, tenants, and small landowning farmers, a radical formation in itself since it overturned respectability norms for women. That women's roles have emerged in the record of Tebhaga, particularly their demands within their localities' gendered social orders and intimate relationships, is also remarkable. For peasant women's actions to gain historical visibility requires a cross-gender examination of normative gendered roles of leadership, honour, hierarchy and respect. For peasant women, famine was not the precondition lor their activism. Mass starvation itself did not loster the communist insistence on women's independent ability, in Dasgupta's words, to 'stand straight'. Instead, peasant women's self-defence against the political and social orders that produced and fueled the famine provided that necessary lesson.

Peasant women successfully resisted the British practices

ItM Cooper, Sbarecropping ant Sbarecroppen' Struggled it Bengal, pp. 270-71.

"Hes Lahiri, Pasturar Reiolt of the Rural Pusu in Bengal. 
of punitive taxation on grain and land. They combatted landowners' total control over landless and land-poor people's lives. They refused to cede their sexual and bodily autonomy to upper caste men or their families. Marik notes a related transformation for middle class activist women in MARS, 'the mass recruitment during the famine and the transformation of the girls from women who had come forward tor social welfare work into militant cadres'.106 Peasant women's activism did not mirror middle class, urban women's experiences exactly. Their fight against sexual and economic exploitation faced different contours of power and privilege than those faced by middle class women. Their demands, most sharply articulated in broader peasant movements, such as Tebhaga, became integral to communist and left-wing women's organising efforts across India. Additionally, MARS learned its lesson well: internationalist aspirations and national campaigns gained heft in rural areas through a sustained focus on local issues of survival. One central precondition for the involvement of peasant women in revolutionary politics was through securing their sexual autonomy and control in their daily lives. Peasant women in the hot Cold War of Asia and Africa exposed and contested the sexual politics of colonial and feudal complicity in the colonies. They were also at the heart of the emerging panAsian, anti-imperialist women's movement and shared these lessons to build women's pan-Asian, anti-imperialist solidarity through their collective refusal of these embodied systems of exploitation.

liki Marik, 'Breaking Through', p. 98. 